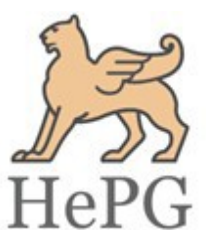

ISSN: 2348-1900

Plant Science Today

$\underline{\text { http://www.plantsciencetoday.online }}$

Mini Review

\title{
Drought stress mitigation in Vigna radiata by the application of root-nodulating bacteria
}

\author{
Diksha Kumari and Dipjyoti Chakraborty*
}

Department of Bioscience and Biotechnology, Banasthali Vidyapith, Rajasthan, 304022, India

\section{Article history}

Received: 31 August 2017

Accepted: 21 October 2017

Published: 04 December 2017

(c) Kamdar \& Chakraborty (2017)

Guest Editor

Hatem Boubakri

\section{Publisher}

Horizon e-Publishing Group

Correspondence

Dipjyoti Chakraborty

¿ cdipjyoti@banasthali.in

\begin{abstract}
Plant growth promoting rhizobacteria (PGPR) facilitates plant growth and are of potential use as bio-fertilizer. Pulses are an important protein source in the vegetarian diet and being legumes harbour members of the Rhizobiaceae that form symbiotic relationships and nodules involved in nitrogen fixation. Vigna radiata is one such pulse crop popular in India. Nodulating bacteria were also found to mitigate biotic and abiotc stress and may be used as an alternative to chemical fertilizer for a sustainable agriculture. Here, we review rhizobial species isolated from $V$. radiata that have offered an efficient drought stress tolerance.
\end{abstract}

\section{Keywords}

drought stress; nitrogen fixation; Rhizobiaceae; sustainable agriculture; Vigna radiata

\section{Citation}

Kumari D, Chakraborty D. Drought stress mitigation in Vigna radiata by the application of root-nodulating bacteria. Plant Science Today 2017;4(4):209-212. doi: 10.14719/pst.2017.4.4.343

\section{Introduction}

Mungbean (Vigna radiata L. Wilczek) is one of the most important "kharif" pulse crops in India. It belongs to leguminosae family. It is extensively grown in tropical and subtropical Asia because of its ecological adaptability. Mungbean is an important source of easily digestible proteins (up to 24\%) and iron (40-70 ppm) for nutritionally balanced cereal-based diets in South and Southeast Asia. It is quite a versatile crop grown for seeds, green manure and forage and it is also considered as Golden Bean because of its nutritional values and suitability for increasing the fertility of soil, as a source of nitrogen. Because of its short life-cycle, it fits well in crop rotation and mixed cropping systems. Actually, the per capita share of pulses in nutrition supply in India with respect to energy, protein and fat is $117.4 \mathrm{~K} \mathrm{cal}, 6.9 \mathrm{~g}$ and $1.0 \mathrm{~g}$ per day, respectively.

\section{Plant growth-promoting Rhizobacteria (PGPR)}

Microorganisms, like plant growth promoting rhizobacteria, play an important role in agricultural systems. Plant growth promoting bacteria are a heterogeneous group of bacteria that can be found in the rhizosphere, at root surfaces 
and in association with roots, which facilitates the establishment of diverse interaction mechanisms responsible for promoting the quality of plant growth directly and/or indirectly. In the last few decades, a large array of bacteria including species of Pseudomonas, Azospirillum, Azotobacter, Klebsiella, Enterobacter, Alcaligenes, Arthrobacter, Burkholderia, Rhizobium, Flavobacteriaum, Bacillus and Serratia have been reported to enhance plant growth $(1,2)$.

PGPR are widely studied because of their potential in increasing plant growth and yield. They act as biofertilizers $(3,4)$ and some provide nitrogen via nitrogen fixation, which can subsequently be used by the plants. They exude phytostimulators (5) that can directly promote the growth of plant, usually by the production of plant hormones. They are also potential biological control agents and can protect plant via root system from phyto pathogenic organisms (6). Application of PGPR is also reported to confer abiotic stress tolerance $(7,8)$. The application of PGPRs in agriculture as inoculants is very attractive since it can substantially reduce the use of chemical fertilizers and pesticides (9).

\section{Root nodulating bacteria as PGPRs}

Biologically active product more appropriately called as "microbial inoculants" contains active strength of selective microorganisms like bacteria, algae, fungi; alone or in combination which helps in increasing crop productivity by biological nitrogen fixation. The rhizobia are a group of Gram-negative bacteria that form species-specific symbioses with legume plant. Nitrogen fixation, the reduction of atmospheric dinitrogen $\left(\mathrm{N}_{2}\right)$ to ammonia $\left(\mathrm{NH}_{3}\right)$, by rhizobia only occurs during symbiosis and provides a significant proportion of available nitrogen in the biosphere. In addition to having nitrogen fixing capacity, some rhizobial inoculants show enhanced nodulation, produce plant growth promoting hormones like indole acetic acid (IAA), secrete siderophores and solubilise phosphates etc $(2,10,11)$.

\section{Drought stress and its mitigation by Rhizobium species}

Roots play an important role in water stress tolerance by reduction in leaf expansion and promotion of root growth. Root length at seedling stage provides a fair estimate about the root growth in field $(12,13)$. Roots have a major role in improving crop adaptation to water stress conditions. In general, deeper and more profuse root systems are able to tap extra water from the soil profile and alleviate drought effects. Root traits like root length, number and root depth, have long been seen as important traits to improve crop adaptation to water stress. The plant growth promoting effects of Rhizobium sp. on $V$. radiata are represented in Table 1.
In a study, root nodules from healthy seedlings of Vigna radiata from farmer's field and yielded three bacterial strains viz., RP1, RP2 and RP3 (14). It was demonstrated that all these strains show growth promoting activities, but RP1 was found to be the most effective in enhancing the growth of plant compared to the other two strains (RP2 and RP3). Several rhizobial species were isolated from the varieties of V. radiata (PM-2, PDM-54, K-851, and PM-5) but only six isolates were short listed on the basis of plant growth promotion and increased plant biomass, maximum nodule numbers and higher nitrogenase activity (15). Maximum range of fresh weights of nodule per plant was shown by R0132, was able to grow at slightly higher temperature $\left(32^{\circ} \mathrm{C}\right)$ and slightly acidic ( $\mathrm{pH}$ 6.0) and alkaline ( $\mathrm{pH}$ 8.0) conditions.

Nine different Rhizobium sp. were isolated from the root nodules of Vigna radiata cultivated in Gujarat and it was observed that isolates AAU6 and AAU-7 can be used as biofertilizers for a better yield (16). In another study, 140 Rhizobium strains were isolated, out of which, six strains (KG-50, WG-57, MG-58, TG-60, MG-64 AND BG-72) were taken for further study. Of them, four isolates showed significant plant growth promotion evidenced by an increase in root and shoot length and number of secondary roots.

Rhizobium phaseoli strains (N1, N2, N4, N10, N11, N13, N20, N22, N25 and N28) were isolated from Mung bean nodules and it was found that N20 isolate offered the best tolerance efficiency to salt stress (18).

In another study, 201 rhizobial strains from were isolated from mothbean, clusterbean and mungbean growing in the arid zones of Rajasthan out of which sixteen showed potential for high PEG and high temperature tolerance under in vitro conditions (19). These strains could further be used in greenhouse experiments for their drought tolerance enhancement potential.

The pulses as cash crops have been always of second choice in India. The "Accelerated pulses production programme" launched in 2010-11 improved pulse crops like chickpea, blackgram, greengram and lentils. However, a lot needs to be done to increase the stagnant pulse production and loss in yield due to drought, salinity and diseases. An understanding of the soil microbiota, especially root nodulating bacteria and its association with specific pulse crops to increase its productivity needs to be addressed.

\section{Acknowledgements}

The authors thank Professor Aditya Shastri, Vice Chancellor, Banasthali Vidyapith, India for providing the necessary facilities and DST for funding under the CURIE project. 
Table 1: Growth promoting characteristics of Rhizobium strains isolated from Mung

\begin{tabular}{|c|c|c|c|}
\hline No & $\begin{array}{l}\text { Rhizobiu } \\
\text { m Strain }\end{array}$ & Growth promoting characteristics & Ref. \\
\hline 1. & WG-57 & $\begin{array}{l}\text { Gram negative, IAA production, Ammonia synthesis, phosphate solubilisation, Proteolytic } \\
\text { enzyme production, amylase activity, cellulase activity. }\end{array}$ & \multirow{5}{*}{$(17)$} \\
\hline 2. & MG-58 & $\begin{array}{l}\text { Gram negative, IAA production, ammonia synthesis, HCN production, phosphate solubilisation, } \\
\text { proteolytic enzyme production, amylase activity. }\end{array}$ & \\
\hline 3. & TG-60 & $\begin{array}{l}\text { Gram positive, IAA production, ammonia synthesis, cellulase activity, lipase activity, proteolytic } \\
\text { enzyme production, amylase activity }\end{array}$ & \\
\hline 4. & MG-64 & $\begin{array}{l}\text { Gram negative, Ammonia production, HCN production, phosphate solubilisation, amylase } \\
\text { activity. }\end{array}$ & \\
\hline 5. & BG-72 & Gram negative, IAA production, ammonia synthesis, amylase activity. & \\
\hline 6. & $\mathrm{RP}-1$ & $\begin{array}{l}\text { IAA production, increase in root and shoot length, HCN production, Siderphore production, } \\
\text { enhancement in nodulation, urea hydrolysis, ammonia production }\end{array}$ & \multirow{3}{*}{$(14)$} \\
\hline 7. & $\mathrm{RP}-2$ & $\begin{array}{l}\text { IAA production, Phosphate solubilisation, Siderphore production, urea hydrolysis, increase in } \\
\text { root and shoot length comparatively less than RP1 }\end{array}$ & \\
\hline 8. & RP-3 & $\begin{array}{l}\text { Increase in root and shoot comparatively less than RP1, ammonia production enhancement in } \\
\text { nodulation. }\end{array}$ & \\
\hline 9. & AAU 2 & $\begin{array}{l}\text { Citrate production, nitrate reduction, organic acid production, } 122 \mathrm{mg} / 100 \mathrm{ml} \text { gum production on } \\
\text { YEMA broth, good growth on } 2 \% \text { sodium chloride concentration, Melanin and Amylase } \\
\text { production }\end{array}$ & \multirow{8}{*}{$(16)$} \\
\hline 10. & AAU 3 & $\begin{array}{l}\text { Nitrate reduction, } 106 \mathrm{mg} / 100 \mathrm{ml} \text { gum production on YEMA broth, good growth on } 2 \% \text { sodium } \\
\text { chloride concentration, Melanin and Amylase production }\end{array}$ & \\
\hline 11. & AAU 4 & $\begin{array}{l}\text { nitrate reduction, } 103 \mathrm{mg} / 100 \mathrm{ml} \text { gum production on YEMA broth, poor growth on } 2 \% \text { sodium } \\
\text { chloride concentration, Amylase production, }\end{array}$ & \\
\hline 12. & AAU 5 & $\begin{array}{l}\text { Citrate reduction, nitrate reduction, } 100 \mathrm{mg} / 100 \mathrm{ml} \text { gum production on YEMA broth, good growth } \\
\text { on } 2 \% \text { sodium chloride concentration }\end{array}$ & \\
\hline 13. & AAU 6 & $\begin{array}{l}\text { Nitrate reduction, organic acid production, good growth on } 2 \% \text { sodium chloride concentration, } \\
\text { Melanin production, maximum amount of gum production }\end{array}$ & \\
\hline 14. & AAU 7 & $\begin{array}{l}\text { Citrate production, nitrate reduction, poor growth on } 2 \% \text { sodium chloride concentration, melanin } \\
\text { production }\end{array}$ & \\
\hline 15. & AAU 8 & $\begin{array}{l}\text { Methyl red test positive, nitrate reduction, } 98 \mathrm{mg} / 100 \mathrm{ml} \text { gum production, melanin production, } \\
\text { Amylase production }\end{array}$ & \\
\hline 16. & AAU 9 & $\begin{array}{l}\text { Methyl red test positive, citrate production, nitrate reduction, } 96 \mathrm{mg} / 100 \mathrm{ml} \text { gum production, } \\
\text { Melanin and Amylase production. }\end{array}$ & \\
\hline 17. & $\mathrm{~N} 20$ & $\begin{array}{l}\text { Produce maximum IAA, increase root length, shoot length, pods dry weight, grain nitrogen, } \\
\text { number of nodules/plant and number of pods/plant of mung bean at different salinity levels. } \\
\text { Maximum visual growth, optical density and population count at high salt concentration }\end{array}$ & (18) \\
\hline 18. & R0034 & $\begin{array}{l}\text { Potential to increase plant biomass, higher number of nodules per plant, and higher nitrogenise } \\
\text { activity }\end{array}$ & \multirow{7}{*}{ (15) } \\
\hline 19. & R0129 & Increase number of nodule per plant, increase fresh weight and dry weight of nodule & \\
\hline 20. & R0132 & $\begin{array}{l}\text { Maximum increase in nodule per plant, increase in fresh and dry weight of nodule, able to } \\
\text { growth at slightly higher temperature and slightly acidic (pH 6.0) and alkaline (pH 8.0) condition. }\end{array}$ & \\
\hline 21. & R0564 & Increase number of nodule per plant, increase fresh weight and dry weight of nodule & \\
\hline 22. & R0789 & Show higher plant biomass, maximum nodule numbers, and higher nitrogenise activity & \\
\hline 23. & R1203 & $\begin{array}{l}\text { Potential to increase plant biomass, higher number of nodules per plant, and higher nitrogenise } \\
\text { activity }\end{array}$ & \\
\hline 24. & AAU 1 & $\begin{array}{l}\text { Citrate utilization, nitrate reduction, organic acid production, } 120 \mathrm{mg} / 100 \mathrm{ml} \text { gum production on } \\
\text { YEMA broth, good growth on } 2 \% \text { sodium chloride concentration, melanin and amylase } \\
\text { production. }\end{array}$ & \\
\hline
\end{tabular}




\section{Conflict of Interest}

The authors declare that they have no competing interests.

\section{Authors' Contribution}

DK drafted the manuscript with collection of references. DC designed the concept, discussed the findings with scientific justification and over all edited the whole manuscript.

\section{References}

1. Glick B R. The enhancement of plant growth by free living bacteria. Can. J. Microbiol. 1995;41:109117. doi: 10.1139/m95-015

2. Vejan P, Abdullah R, Khadiran T, Ismail S, Boyce A $\mathrm{N}$. Role of plant growth promoting rhizobacteria in agricultural sustainability - A Review. Molecules 2016;21(5):573. doi: 10.3390/molecules21050573

3. Vessey J K, Plant growth promoting rhizobacteria as biofertilizers. Plant Soil. 2003;255:571- 586. doi: 10.1023/A:1026037216893

4. Sruthilaxmi C B, Babu S. Microbial bio-inoculants in Indian agriculture: Ecological perspectives for a more optimized use. Agric. Ecosyst. Environ. 2017;242:23-25. doi: 10.1016/j.agee.2017.03.019

5. Steenhoudt O, Vanderleyden J. Azospirillum, a freeliving nitrogen-fixing bacterium closely associated with grasses: genetic, biochemical and ecological aspects. FEMS Microbiol. Rev. 2006;24(4):487-506. doi: 10.1111/j.1574-6976.2000.tb00552.x

6. Liu K, Newman M, McInroy J A, Hu C H, Kloepper J W. Selection and Assessment of plant growthpromoting rhizobacteria for biological control of multiple plant diseases. Phtopathol. 2017;107(8):928936. doi: 10.1094/PHYTO-02-17-0051-R

7. Ngumbi E, Kloepper J. Bacterial-mediated drought tolerance: current and future prospects. Appl. Soil Ecol. 2016;105:109-125. doi: 10.1016/j.apsoil.2016.04.009

8. Vurukonda S S K P, Vardharajula S, Shrivastava M, Skz A. Enhancement of drought stress tolerance in crops by plant growth promoting rhizobacteria. Microbiol. Res. 2016;184:13-24. doi: 10.1016/j.micres.2015.12.003

9. Wallenstein M D. Managing and manipulating the rhizosphere microbiome for plant health: A systems approach. Rhizosphere. 2017;3(2):230-232. doi: 10.1016/j.rhisph.2017.04.004
10. Ahemad $M$ and Kibret $M$. Mechanisms, applications of plant growth promoting rhizobacteria: current perspective. J. King Saud Univ. Sci. 2014;26(1):1-20. doi: 10.1016/j.jksus.2013.05.001

11. Kuan K B, Othman R, Rahim K A, Shamsuddin Z H. Plant growth-promoting rhizobacteria inoculation to enhance vegetative growth, nitrogen fixation and nitrogen remobilisation of maize under greenhouse conditions. PLoS One 2016;11(3):e0152478. doi: 10.1371/journal.pone.0152478

12. Ali M A, Abbas A, Awan S I, Jabran K, Gardezi S D A. Correlated response of various morphophysiological characters with grain yield in sorghum land races at different growth phases. J. Anim. Plant Sci. 2011;21(4):671-679.

13. Rajendran $\mathrm{R}$ A, Muthiah A R, Manickam A, Shanmugasundaram P, Joel A J. Indices of drought tolerance in sorghum (Sorghum bicolor L. Moench) genotypes at early stages of plant growth. Res. J. Agric. Biol. Sci. 2011;7:42-46.

14. Rajpoot $\mathrm{P}$ and Panwar $\mathrm{K}$ S. Isolation, characterization of rhizobia and their effect on Vigna radiata plant. Octa. J. Biosci. 2013;1(1):69-76.

15. Neeraj, Gaurav S S, Chatterjee S C, Sachin, Chandra M. Efficient nitrogen fixing rhizobial isolate infecting Vigna radiata I. Asian J. Agric. Sci. 2009;1(2):62-65.

16. Bhatt S, Vyas R V, Shelat H N, Mistry S J. Isolation and identification of root nodule bacteria of mung bean (Vigna radiata L.) for biofertilizer production. Int.J. Res. Pure App. Microbiol. 2013;3(4):127-133.

17. Geetha K, Venkatesham E, Hindumathi A, Bhadraiah B. Isolation, screening and characterization of plant growth promoting bacteria and their effect on Vigna radiata (L.) R.Wilczek. Int. J. Curr. Microbiol. App. Sci. 2014;3(6):799-809.

18. Zahir ZA, Shah MK, Naveed M, Akhter MJ. Substrate-dependent auxin production by rhizobium phaseoli improves the growth and yield of Vigna radiata L. under salt stress conditions. J. Microbiol. Biotechnol. 2010;20(9):1288-1294. doi: 10.4014/jmb.1002.02010

19. Mondal H K, Mehta S, Kaur H, Gera R. Characterization of abiotic stress tolerant rhizobia as PGPR of mothbean, clusterbean and mungbean grown in hyper-arid zone of Rajasthan. Int. J. Bioresour. Stress Manage., 8(2):309-315. 